\title{
Mimese, pintura e poesia na Poética aristotélica
}

\author{
Christiani Margareth de Menezes e Silva \\ chrisfilo@ig.com.br \\ Universidade Estadual de Santa Cruz, Santa Cruz, Brasil
}

resumo Este artigo procura compreender a noção de mimese na Poética de Aristóteles. Tanto nos autores do século V a.C., quanto em Platão e em Aristóteles, os cognatos de mimesis desconhecem um campo específico de aplicação, além disso, apresentam acepções simular e emular - que por vezes se identificam e outras vezes se contradizem. Apesar desta ambivalência de mimesis e cognatos nos autores do século $V$ a.C., e no próprio Aristóteles, na Poética o exemplo da pintura elucida melhor o sentido de mimesis e cognatos no contexto das mimetikai technai (artes miméticas).

palavras-chave Mimese; simulação; emulação; techne; pintura; poesia

Partamos inicialmente de uma constatação: Aristóteles, em nenhum lugar de sua obra, define o que entende por mimesis. Em geral, o sentido desse substantivo grego ficou atrelado aos escritos e trechos que em Aristóteles, e mesmo em Platão, tratam das mimetikai technai (artes miméticas) circunscrevendo a compreensão do que seja mimesis ao contexto das atividades de pintores, músicos, dançarinos, escultores e poetas. ${ }^{2}$

$\mathrm{Na}$ verdade, o substantivo mimesis e cognatos não encontram uma delimitação de contexto nítida, e isso já é uma característica de tais vocábulos nos predecessores de Platão e Aristóteles, isto é, os autores do séculoV a.C., e mesmo em Homero (séc. IX-VIII a.C.), ${ }^{3}$ fato que implica, muitas vezes, dificuldades interpretativas que desafiam a compreensão de qual acepção dos vocábulos está presente. Essa variedade de contextos demonstra que tal grupo de palavras não se restringe a descrever e 
caracterizar o que fazem os autores das mimetikai technai, seu campo de aplicação é mais extenso.

No caso de Aristóteles, os cognatos do verbo mimeomai aparecem tanto nas obras tradicionalmente relacionadas à Poética-Ética a Nicômaco, Política, Retórica -, como nos Tópicos, Magna Moralia, Econômicos, Constituição de Atenas, Metafísica, Física, Da Geração e da Corrupção, Meteorológicos e História dos Animais, e em alguns fragmentos e obras ainda consideradas não autênticas. Mesmo assim, Stephen Halliwell acredita que o sentido básico dos cognatos encontra-se na Poética, mas tal afirmativa é de difícil comprovação, e isso se deve seja à falta de definição por parte de Aristóteles, seja aos diversos empregos no Corpus que implicam questões além das artes miméticas descritas na Poética, como a ontologia e a epistemologia aristotélicas. $^{4}$

Ainda que concordemos com Halliwell quanto a que o sentido de mimesis na Poética seja o sentido primário em Aristóteles, a não definição dessa noção na obra deixa a questão em aberto. Segundo Halliwell, esse sentido primário de mimesis referir-se-ia a sua aplicabilidade na descrição dos trabalhos dos poetas, escultores, pintores, dançarinos e músicos, e justificar-se-ia no capítulo 1 da Poética e no livro I da Retórica, capítulo 11. Para ele, os outros trabalhos de Aristóteles em que aparecem os vocábulos do mesmo grupo trariam pouco esclarecimento ao uso primário, sendo então a noção de mimesis uma característica típica das technai hoje classificadas dentro do grupo que conhecemos como "belas-artes". 5 Mas a questão não é tão simples, visto que deveríamos ter de antemão uma definição dada por Aristóteles para podermos afirmar com convicção que mimesis é uma noção que se aplica apenas a tais technai e não a outras, ou que seu sentido primário esteja ligado a elas. E, como dissemos antes, os usos em outros contextos do pensamento do filósofo atestam que essa noção não se restrinja a um campo, ou sentido primordial, específico.

Devemos lembrar que, em geral, Aristóteles ao definir algo, faz a delimitação do gênero ao qual pertenceria e, ao dividir em espécies as atividades no primeiro capítulo da Poética, classificando os tipos de poesia, parece sugerir que haja também um gênero ao qual pertenceriam essas espécies de atividades, delimitando-as pelo aspecto mimético. Gerald Else nota semelhanças do início da Poética com o início de um dos trabalhos biológicos de Aristóteles - Partes dos Animais - onde há essa classificação 
por gênero, mas essa semelhança não garante que o procedimento de Aristóteles seja o mesmo na Poética (ELSE, 1957, p. 15).

Por outro lado, Paul Ricoeur nota que não há exatamente a definição de um gênero de mimetai (imitadores) na Poética, assim como não há definição de nosso substantivo, embora Aristóteles proceda como se estivesse delimitando um gênero que fosse caracterizado por ser mimético, ao indicar as espécies de poiesis no início da Poética. Mas Ricoeur também entende que a explicação do que seja mimesis na Poética seria dada pela classificação das espécies de poesia e pela relação dessas com os meios, os modos e os objetos como se apresenta a imitação, não necessitando, assim, de uma definição que indique um gênero (RICOUER, 2000, p. 66-67).

Apesar da cautela que devemos ter para compreender mimesis na Poética, mormente por Aristóteles não lhe ter dado uma definição, podemos entender os sentidos que ele dá aos cognatos de mimeisthai graças às acepções que estes vocábulos possuem, pelo emprego que os autores do século $\mathrm{V}$ a.C. fazem deles e pelas relações que esta noção tem com as atividades presentes na Poética. Por isso, não é incomum vermos diversos comentadores e tradutores da Poética analisarem algumas ocorrências da noção de mimese nos predecessores de Aristóteles procurando esclarecer o uso que ele faz desse vocábulo.

O substantivo grego mimesis deriva do verbo mimeomai que, por sua vez, de acordo com Gerald Else e Göran Sörbom, derivam do substantivo mimos, mas o problema é determinar o significado original de mimos (ELSE, 1958, p. 74; SÖRBOM, 1966, p. 16-17). ${ }^{6}$ Para Sörbom e Else, mimos diz respeito a um tipo de apresentação. Provavelmente, era um tipo de performance que retratava situações bem conhecidas por seus espectadores, o que não significa que os mimoi fossem retratos no sentido estrito, detalhando traços particulares com minúcia, apenas que essa retratação deveria apresentar aspectos que possibilitassem, da parte de quem observava, a identificação do modelo ali considerado.

De acordo com Else, primordialmente, quer na dança quer na música, imitavam-se nos mimoi características visuais e ações. Esse vocábulo originou-se na Sicília e os seus cognatos passaram à esfera ático-jônica, expandindo seu uso para toda Grécia antiga na terça parte do século V. Progressivamente, os cognatos de mimeisthai passaram a significar, genericamente, "imitar outra pessoa", "fazer como" ou "fazer o que ela faz". E 
assim, segundo Else, paralelamente, ou talvez pouco depois, esses vocábulos também passaram a referir-se não só a uma performance, mas a um contexto amplo de atividades humanas, que não se limitavam às apresentações dos mimoi (ELSE, 1958, p. 87).

Else nota também que o substantivo mimos é tão raro no século $\mathrm{V}$ a.C. quanto o substantivo mimesis. Isso porque, de acordo com ele, mimos designava um tipo de performance de pessoas de baixa condição. ${ }^{7}$ Apesar da raridade do substantivo mimesis nos autores do século $\mathrm{V}$ a.C., alguns vocábulos, como o verbo mimeomai e o substantivo mimema não são tão raros assim. Os cognatos do verbo mimeomai já aparecem, por exemplo, em Homero (séc. IX-VIII a.C.) no Hino a Apolo ${ }^{8}$, passagem na qual, concordam os estudiosos, mimeomai tem o sentido de simular algo, isto é," fazer o mesmo que".

Procurando melhor compreender os significados das palavras ligadas a mimeisthai, Else resume, assim, seus sentidos no século $\mathrm{V}$ a.C.: a) representação de aparências, ações, e/ou expressões de animais ou de falas dos homens, canção ou dança, isto é, um tipo de simulação como a dos mimoi; b) imitação de ações de uma pessoa por outra, sem mimo; c) uma réplica, imagem ou efígie de uma pessoa ou coisa através de algo, isto é, o mimema. Para Else, o primeiro sentido seria o primário, os outros dois, suas extensões. ${ }^{10}$

Como Else, Sörbom acredita que houve um desenvolvimento desses vocábulos, mas não como uma generalização do significado original em “imitar". Para ele, o que ocorreu foi uma expansão do emprego dos vocábulos ligados a mimeisthai, não uma mudança do sentido original para um sentido geral, como crê Else. Sörbom concorda quanto à origem siciliana de mimos e acredita que esse vocábulo é primordial para se entender a família de mimese, mas acredita também que o verbo mimeisthai, e talvez os vocábulos de mesma raiz, empregaram-se originalmente como metáfora.

O desenvolvimento seguiu-se de duas maneiras para Sörbom: 1) aos poucos se ampliaram os fenômenos aos quais essas palavras eram aplicadas e 2) o sentido metafórico delas foi-se extenuando. Ao contrário de Else, para Sörbom, mimeisthai não teria seu significado técnico de "performance de mimo", mas significaria "comportar-se como um ator de mimo" e "comportar-se como no mimo" (isto é "imitar um mimo"), diferenciando-se, aqui, apenas o ator do gênero dramático. Assim, o sentido originário 
de mimeisthai ligado ao substantivo mimos oscila entre significar "o que o ator de mimos faz" e "pessoas se comportando como os atores de mimos" (SÖRBOM, 1966, p. 24-37). Rigorosamente, para Sörbom, mimeisthai significaria "imitar um mimo" e, consequentemente, "imitar aquele que imita por profissão". Como toda metáfora é extenuada até o seu esgotamento, isso fez com que tais palavras adquirissem um campo amplo e não se referissem apenas à atuação de alguém nos mimoi, mas a qualquer tipo de exibição (SÖRBOM, 1966, p. 37-40).

Sörbom também acha desnecessária uma classificação dos significados da família de mimeisthai, como faz Else. Para ele, não há uma diversidade de significados, mas sempre um alargamento do sentido metafórico. Apesar disso, de maneira parecida com Else, Sörbom admite que esse grupo de palavras ocorre em contextos muito diversos. Ele também admite a acepção de emulação que mimeisthai adquirirá, enquanto dê ao verbo o sentido de iludir e enganar, e não diferencie claramente emulação de simulação, apesar de esta, às vezes, significar algo bem diverso daquela, e também que essas acepções apareçam de modo indissociável.

Portanto, de modo bem geral, nos autores do século V a.C., os cognatos de mimeisthai exprimem ora a imitação de sons de animais e sotaques estrangeiros, ora a reprodução do que é imitado, o mimema propriamente dito, como imagens pintadas e esculpidas em réplicas; ora designa uma apresentação pública, representação por meio de atores, simulação de certos aspectos da vida. Mimese pode significar também, emulação, ou seja, a imitação de um comportamento tomado como modelo, ou indica o disfarce, a emulação e a simulação juntas. Na imitação ainda percebemos um aspecto cognitivo, pois aquele que quer imitar, seja na emulação de um sotaque ou comportamento, e mesmo na techne que simula coisas reais ou imaginárias, como as pinturas e esculturas, precisa aprender o ofício ou o jeito de falar e de se comportar. Outra questão que se liga a esse grupo de palavras é a possibilidade do engano que, segundo Else e Sörbom, está atrelada a esses vocábulos desde suas origens nos mimoi. ${ }^{11}$

Resumindo o que consideramos até aqui, mimese significa "fazer o mesmo que", e isso em duas ou três acepções: se na acepção simulativa, significa "fazer o mesmo que"; se na emulativa, apresenta o sentido de "tentar fazer o mesmo que"; e, em último caso, podemos considerar a identidade uma acepção de mimeomai, que significa "fazer exatamente o mesmo". O 
grupo de palavras ligadas a mimeomai não conhece uma delimitação de área, por ser aplicada ao produzir, ao agir, ao ser e ao ter (Cf.VELOSO, 1999, p. 94).

Em suma, a imitação na acepção simulativa exibe ou demonstra algo e a imitação enquanto emulação designa o desejo de aprender e de seguir um mestre ou um modelo exemplar, que pode até ser superado. Dificil é estabelecer uma distinção de qual acepção está em jogo nos autores antigos, já que elas muitas vezes estão presentes de maneira indissociável, o que, claro, influi na interpretação desses vocábulos. A identidade seria o caso limite e tanto simulação quanto emulação implica identidade, embora não de modo completo, já que há semelhanças e diferenças na emulação e na simulação, quer dizer, há uma relação em que se percebe o que é emulado ou simulado, só possível pela aproximação da semelhança e pela distância da diferença. A mimética implica, por assim dizer, proximidade e distância, próprios da imitação (SÖRBOM, 1966, p. 33 e 40).

$\mathrm{Na}$ Poética essas acepções, assim como alguma dificuldade em interpretá-las, estão presentes, embora o exemplo da pintura, como veremos, seja esclarecedor para entendermos mimesis na obra. No início dela,Aristóteles diz que escultores e pintores se servem de cores e figuras para mimetizar, e os poetas, músicos e dançarinos valem-se do ritmo, da harmonia e da linguagem $(\log o s)$ para tarefa semelhante, não importa se usados separadamente ou em conjunto. ${ }^{12}$ Aristóteles considera a formação dos diversos estilos de poesia como uma história que aos poucos foi se desenvolvendo até chegar às espécies de poesia que ele expõe na Poética, especialmente a tragédia, a comédia e a epopeia.

Assim, conforme a índole dos poetas, as espécies de poesia foram se diferenciando entre aqueles que imitam ações graves (semnoteroi), isto é, os poetas "sérios" e os poetas "inferiores", "fáceis" (eutelesteroi). De rudes improvisações e conforme o caráter dos poetas, a poesia foi-se desenvolvendo e aperfeiçoando:

Sendo, pois, a imitação própria da nossa natureza (e a harmonia e o ritmo, porque é evidente que os metros são parte do ritmo), os que ao princípio foram mais naturalmente propensos para tais coisas pouco a pouco deram origem à poesia, procedendo desde os mais toscos improvisos. A poesia tomou diferentes formas, segundo a índole particular [dos poetas]. Os de mais alto ânimo [semnoteroi] imitam as 
ações nobres e das mais nobres personagens; e os ["mais inferiores", eutelesteroi] voltaram-se para as ações ignóbeis, compondo, estes, vitupérios, e aqueles, hinos e encômios. ${ }^{13}$

Dessa maneira, os mais naturalmente dotados (pephykotes) foram aos poucos dando origem à poesia, a partir de improvisações, ou seja, segundo a physis, não ainda segundo a techne dos poetas, como será considerado no cap. 8. Logo a poesia ultrapassou as improvisações e conforme os ethe dos poetas - semnoteroi ou eutelesteroi -, sua mimese de ações distinguiu-se em belas, elevadas, ou vis, baixas. Segundo Yebra, estes poetas, que precederam Homero, foram decisivos no desenvolvimento da poesia, embora Aristóteles considere que Homero tenha um lugar de maior destaque na história da poesia, já que ele está na origem mesmo da comédia, não apenas na origem da tragédia. ${ }^{14}$

Então, conforme sua índole, os poetas foram preferindo uma ou outra espécie de poesia. Ao estabelecer a ligação do caráter dos poetas com as ações a serem imitadas nas três espécies de poesia - comédia, epopeia e tragédia -, Aristóteles estaria entendendo a imitação destes na acepção de emulação própria dos cognatos de mimesis como vimos. ${ }^{15}$ Lembremos que a emulação, além de ser uma das acepções de mimese, também é uma emoção analisada no livro II da Retórica, junto à inveja; emular (dzeloun) é admirar algo, que pode ser tomado como modelo: "E esta é a causa de que nos infortúnios não queremos ser vistos por aqueles que em outro momento nos emulavam, porque os êmulos são admiradores."16

Mas, segundo Richard Janko, o único caso certo da acepção emulativa de mimeisthai na Poética é o seguinte:

Se a tragédia é imitação de homens melhores que nós, importa seguir o exemplo dos bons retratistas, os quais, ao reproduzir a forma peculiar dos modelos, respeitando embora a semelhança, os embelezam. Assim também, imitando homens violentos, ou fracos, ou com tais outros defeitos de caráter, devem os poetas sublimá-los, sem que deixem de ser o que são: assim procederam Agatão e Homero para com Aquiles, paradigma de rudeza. ${ }^{17}$

Os bons retratistas são o paradigma que o bom poeta deve seguir, e mesmo assemelhando o personagem ao homem médio, este deve ser sempre 
um "melhor do que nós". ${ }^{18}$ Se considerarmos como Janko que este seja o único passo onde a acepção emulativa de mimeisthai esteja claramente em jogo, o paradigma da pintura, como veremos, aparece ao longo de toda Poética, o que indica que a acepção de emulação talvez esteja sempre presente na obra. E, além disso, quando Homero é tomado como paradigma, encontramos a emulação, pois ele deve ser o poeta emulado pelos demais. ${ }^{19}$

Ao analisar as espécies de poesia, Aristóteles diz que o que diferencia uma espécie da outra são os meios, os objetos e os modos da mimese. O meio pelo qual a poesia mimetiza é o metro ou verso, mas Aristóteles destaca o fato de não ser a metrificação o que distingue o poeta daquele que não o é, e para ilustrar tal consideração ele contrapõe Homero a Empédocles, observando que este último seria mais um naturalista (physiologos) do que poeta e que Homero seria propriamente um poeta.

Dessa forma, a distinção entre um e outro não fica evidente, porque tanto Homero como Empédocles (490-435 a.C.) versificam e, segundo Diógenes Laércio, no Dos Poetas Aristóteles reconhecia Empédocles como dotado de estilo poético semelhante ao de Homero, mas não é bem isso que ocorre na Poética. ${ }^{20}$ Aristóteles parece aqui querer distinguir entre os discursos de um e de outro, e essa distinção parece recair sobre o conceito de mimese, mas, por não nos ter dado ele uma definição precisa dessa noção, a distinção entre Homero e Empédocles não fica completamente clara.

Se não é a métrica, ou versificação, que distingue o poeta de autores de tratados sobre a natureza (physis), provavelmente o fato de o poeta criar um enredo (mythos) irá distingui-lo daquele que se atém a entender e explicar as relações presentes na physis; porque, para Aristóteles, "o poeta deve ser mais fabulador que versificador; porque ele é poeta pela imitação e porque imita ações." ${ }^{21}$ Poderíamos dizer que não é a forma, mas o conteúdo que distingue a poesia da filosofia embora, por não termos a definição de mimese, tal afirmação não possa ser comprovada definitivamente. Lembremos que na Retórica, Aristóteles atribui às próprias palavras, semelhantemente a Platão, em um sentido geral, a noção de mimese, o que não nos autoriza a afirmar que apenas a palavra poética seja mimética:

Assim, pois, os que a princípio iniciaram este movimento [do estilo e da recitação] foram, como é natural, os poetas, posto que as palavras são 
imitações [onomata mimemata estin] e, por outro lado, de todos os nossos órgãos, a voz é o mais adequado à imitação ${ }^{22}$

Quanto ao objeto da mimese poética, os homens em ação, esses apresentam caracteres (ethe) que representam ou os homens superiores, ou inferiores ou iguais aos demais, e a distinção dos caracteres é feita de modo parecido ao daquele que fazem os pintores, isto é, o paradigma que o poeta deve seguir está na pintura:

Mas, como os imitadores imitam homens que praticam alguma ação, e estes, necessariamente, são indivíduos de elevada ou de baixa índole (porque a variedade dos caracteres só se encontra nestas diferenças [e, quanto a caráter, todos os homens se distinguem pelo vício ou pela virtude]), necessariamente também sucederá que os poetas imitam homens melhores, piores ou iguais a nós, como o fazem os pintores: Polignoto representava os homens superiores; Pauson, inferiores; Dionísio representava-os semelhantes a nós. Ora, é claro que cada uma das imitações referidas contém estas diferenças, e que cada uma delas há de variar, na imitação de coisas diversas, desta maneira. ${ }^{23}$

Desse modo, o poeta deve proceder tomando como modelo, paradigma, a retratação pictórica, tendo como referente o real direto, como atesta a expressão "semelhantes a nós", que provavelmente se refere aos contemporâneos de Aristóteles, conquanto a maioria das retratações feitas pelos poetas tivesse como fonte para as composições ou a tradição histórica ou a mitologia. De acordo com Dupont-Roc e Lallot, este passo indica tanto os autores da mimese (os imitadores), quanto pode indicar mais duas coisas: ou o que serve de modelo à mimese, ou o que é produzido (poleu) pela mimese. ${ }^{24}$

Este passo da Poética é importante, segundo Sörbom, por deixar clara a ambivalência de acepções presentes na família de mimese. $\mathrm{O}$ exemplo de Aristóteles é tirado da pintura, e é associado ao modo como os poetas devem "retratar" suas personagens. Sörbom afirma que o uso do verbo mimeisthai nesta passagem pode referir-se ao modelo envolvido, semelhantemente ao que faz um aluno ao imitar ou fazer a mesma coisa que seu professor, ele imita o professor, tomando-o como modelo a ser seguido, isto é, ele o imita na acepção emulativa; no caso do trecho da Poética transcrito acima, 
são os pintores que são emulados pelos poetas. Por outro lado, Sörbom nos lembra, o verbo também pode indicar não apenas o modelo, mas o conteúdo representacional do mimema, uma ideia, como, por exemplo: "crianças obedecendo a seus pais" ou "atleta belo jogando um disco".

De acordo com Sörbom, os gregos não distinguiam "modelo" daquilo que Sörbom chama de subject-matter, ou seja, o conteúdo representacional do mimema. E isso sempre implica a vacilação quanto a determinar o objeto de mimeisthai; como ele obseva, nem sempre as pinturas e as esculturas gregas desse período copiavam algo em particular, um objeto, ou uma pessoa, mas muitas vezes elas exemplificavam e manifestavam uma ideia geral, como antes dissemos. Nesse caso particular, Sörbom identifica o objeto de mimeisthai como subject-matter, porque há aqui, de acordo com sua interpretação, a indicação do conteúdo do que deve aparecer ao observador. ${ }^{25}$ Tal conteúdo refere-se ao paradigma do ethos, que separará a comédia da tragédia, uma representando o grave e elevado a outra, o vil, o baixo. ${ }^{26}$

Os modos são outro critério que distingue a mimese dos poetas, são eles: narrativo e dramático. O primeiro modo, narrativo, é caracterizado por ser a narração da ação feita pelo poeta, o qual assume a voz de uma personagem, ou por ser a ação narrada pelo próprio poeta, em primeira pessoa; já o modo dramático é caracterizado pelo fato da narração ser feita pelos próprios personagens como autores da ação. Como nos revela Valentín Garcia Yebra, em comentário à sua tradução do texto, Aristóteles estabelece duas oposições: uma entre a poesia épica e a poesia dramática, e a outra entre os dois tipos de poetas épicos, o que narra através de uma personagem e o que narra na primeira pessoa.

Nesse caso, não haveria aqui a clássica divisão da poesia em três gêneros: narrativo, dramático ou mimético e misto ou comum. Else entende que a passagem se refere aos atores, os que fazem a imitação; mas, em sentido estrito, quem imita são os poetas. Yebra chama a atenção para o fato de que entender que são os atores que executam a ação teria como resultado entender que o poeta dramático imitaria os atores, quando o que realmente acontece é que ele imita mediante os atores, que fazem as personagens do mythos composto pelo poeta: ${ }^{27}$

Homero, que por muitos outros motivos é digno de louvor, também o

é porque, entre os demais, só ele não ignora qual seja propriamente o mister do poeta. Porque o poeta deveria falar o menos possível por conta 
própria, pois, assim procedendo, não é imitador [mimetes]. Os outros poetas, pelo contrário, intervêm em pessoa na declamação, e pouco e poucas vezes imitam [mimoutai], ao passo que Homero, após breve intróito, subitamente apresenta varão ou mulher, ou outra personagem caracterizada - nenhuma sem caráter, todas as que o têm. ${ }^{28}$

Segundo Dupont-Roc e Lallot, não imita quem fala em sua própria pessoa e, por isso, Aristóteles entende que o poeta deva falar o mínimo possível na primeira pessoa, no poema (DUPONT ROC; LALLOT, 1980, p. 248). Em geral, o poeta fala em primeira pessoa no introito ou proêmio, o que servia, na poesia, para apresentar o enredo (mythos) ao espectador ou ao leitor. O proêmio é o que nos dá a conhecer o mythos, que é considerado a alma da poesia. Mas nem sempre o proêmio é prólogo, ou seja, nem sempre vem no início do poema, e nem sempre é o poeta quem fala, podendo mesmo, às vezes, ser uma personagem a falar nele, como ocorre em Édipo Rei, onde o proêmio aparece na segunda metade da obra, e é Édipo, uma personagem, quem fala. ${ }^{29}$ Alguns comentadores veem nesse passo a exclusão da narrativa épica como mimética, mas, segundo Jean Lallot, o que se exclui não é a narração épica, e sim o proêmio; como já disse Aristóteles, imita, ao narrar, quem introduz caracteres, ${ }^{30}$ o poeta deve evitar alongar-se no proêmio, para já começar a ação. Novamente aqui estamos em dificuldades, pois Aristóteles, como acima notamos, diz na Retórica que as palavras são mimese, afirmação esta que nos faz desconfiar que todo tipo de discurso se caracterize pela mimética, talvez porque, por meio do discurso, algo se apresente a nós e, no caso das poesias épica, trágica e cômica, teríamos personagens agindo, conforme um enredo (mythos).

Outra passagem da Poética que sublinha novamente a ambivalência do verbo mimeisthai, segundo Sörbom, é a seguinte:

O poeta é imitador, como o pintor ou qualquer outro ["fazedor de imagens"]; por isso, sua imitação incidirá num destes três objetos: coisas quais eram ou quais são, quais os outros dizem que são ou quais parecem, ou quais deveriam ser. Tais coisas, porém, ele as representa mediante uma elocução que compreende palavras estrangeiras e metáforas, e que, além disso, comporta múltiplas alterações, que efetivamente consentimos ao poeta. ${ }^{31}$ 
Trata-se, pois, daquilo que se imita. O poeta tem, então, três possibilidades ao imitar: ou representa as coisas como eram ou são, ou seja, tendo as coisas presentes e passadas por referência; ou ele imita as coisas como os outros dizem que são ou parecem ser, ou conforme opina a maioria; ou ainda como elas deveriam ser, criando uma situação. ${ }^{32}$

Dessa forma, por meio de mimese Sófocles, por exemplo, apresenta as pessoas melhores do que são, enquanto Eurípides representa os homens como eles são; também é possível a imitação corresponder à opinião comum, como o que contam os poetas sobre os deuses, ou o que a tradição transmitiu a respeito deles. Mesmo havendo referência à tradição, isso não significa que o poeta deva falar como o historiador, procurando apresentar os fatos como eles ocorreram. Ao poeta, para Aristóteles, é concebível poder expor até mesmo o falso, e novamente Homero é citado como um modelo a seguir, visto que ele ensinou a maneira como dizer o falso e ser convincente:

Além disso, quando no poeta se repreende uma falta contra a verdade, há talvez que responder como Sófocles: que representava ele os homens tais como devem ser, e Eurípides, tais como são. E depois caberia ainda responder: os poetas representam a opinião comum, como nas histórias que contam acerca dos deuses: essas histórias talvez não sejam verdadeiras, nem melhores; talvez as coisas sejam como pareciam a Xenófanes; no entanto, assim as contam os homens. ${ }^{33}$

A mimese corresponde ao verdadeiro ao representar os homens como eles são, mas o poeta pode representar o impossível, não obstante isso seja considerado por Aristóteles um erro, no qual o poeta até pode incorrer, conquanto cause o efeito de surpresa, caso contrário, ele é um erro "injustificável" (Poética, 25, 1460 b26). Preferentemente, não se deve representar o impossível, mas se ocorrer, este deve causar efeito de surpresa, além de ser plausível, e assim o uso do impossível é admitido. A poesia, que é mimese, está não no campo da realidade, embora tenha com ela certa correspondência, mas toda mimese dos poetas está no campo do plausível, e os poetas podem representar o possível e o impossível, mas seguindo determinados critérios, que são a necessidade (ananke) e a verossimilhança (eikos).

Até aqui vimos que as acepções de emulação e simulação aparecem na Poética, nem sempre de maneira clara, seja pelo estado do texto 
- interpolado e fragmentário ${ }^{34}$-, seja pelas dificuldades interpretativas da ambivalência de mimeomai. Em uma passagem no início da Poética, quando Aristóteles fala acerca da origem da poesia, ele precisa o que entende por mimese na obra, e o exemplo usado para essa precisão de sentido é aquele que ele retoma em algumas partes do texto, a pintura:

Duas causas parecem ter dado origem à poesia, e ambas naturais. $\mathrm{O}$ imitar é natural no homem desde a infância, e nisso se distingue dos outros animais, pois é o mais inclinado à imitação e pela imitação adquire os primeiros conhecimentos, e todos se comprazem com as imitações realizadas. Prova disto é o que ocorre na prática; pois há coisas que ao olharmos nos aflige, mas nós gostamos de ver as imagens executadas com a maior exatidão possível, por exemplo, as figuras de animais repugnantes e de cadáveres. E também a causa disto é que aprender é prazeroso, e não apenas para os filósofos, mas igualmente para os demais homens, embora compartilhem disso em menor grau. Por isso comprazem-se vendo as imagens, pois acontece que ao contemplálas aprendem e deduzem o que é cada coisa, por exemplo, que este é aquele [houtos ekeinos]. Porque, se alguém não viu antes o retratado, não é a imitação que produzirá prazer, mas a execução da obra, ou a cor ou alguma causa semelhante. ${ }^{35}$

Ao estarmos diante de um mimema percebemos o que ele apresenta, seja homem, seja animal, seja uma figura mitológica, e esse reconhecimento vem seguido da expressão "este é aquele" ${ }^{36}$ A pintura simula algo, identificamos e percebemos o que ela manifesta como se fosse aquilo que é mimetizado, e nos expressamos reconhecendo o retratado. Esta é uma das características mais marcantes da imitação, o reconhecimento do que ela apresenta: a semelhança que a coisa pintada mostra com a coisa mesma.

É isso que causa em nós certa admiração e prazer, por isso podemos nos deleitar com o reconhecimento de coisas repugnantes ou dignas de dar medo, como os cadáveres e os animais selvagens; admiramo-nos com o que o mimema mostra. ${ }^{37}$ No caso de não reconhecermos o que a pintura apresenta, o prazer que a pintura proporciona será de outra natureza, não estará no reconhecimento da semelhança, mas na apreciação do uso das cores, dos traços etc. Podemos entender por essa passagem da Poética que o prazer ligado à noção de mimesis é de ordem cognitiva. 
Encontramos na Retórica uma asserção que reforça o que consideramos sobre essa passagem da Poética:

Da mesma maneira, o aprender e o admirar são na maioria da vezes prazerosos, porque, no admirar está contido o desejo de aprender - de modo que o admirável é desejável - e, no aprender se dá um estado conforme à natureza. Se contam entre as coisas prazerosas fazer e receber o bem, já que, de um lado, receber um bem significa obter o que se deseja e, por outro lado, fazer um bem supõe que se possua e seja superior: ambas coisas a que todos aspiram. E, pela mesma razão que é prazeroso o que serve para fazer um bem, é igualmente prazeroso aos homens corrigir a seus semelhantes e completar o que está incompleto. E, como aprender e admirar é prazeroso, é também necessário que o seja o que possue as mesmas qualidades: por exemplo, o que constitui uma imitação, como a escrita, a escultura, a poesia e em geral todas as boas imitações, mesmo se o objeto imitado não for agradável; porque não é com isto que se sente prazer, mas pensar que "este é aquele" [touto ekeino], de sorte que o resultado é que aprendemos alguma coisa. São prazerosas igualmente as aventuras e o salvar-se por pouco dos perigos, pois todas essas coisas causam admiração [thaumasta tauta]. ${ }^{38}$

O saber, como diz o início da Metafísica, é aquilo que é naturalmente desejado, pois nos admiramos com as coisas que contemplamos e desejamos descobrir por que elas são da forma que são, e a aprendizagem (mathesis) é a busca pela compreensão do que se desconhece. A compreensão é da ordem do maravilhoso (thaumaston), além disso, a aprendizagem, se em certas circunstâncias pode causar dor, é também prazerosa, como atesta o tratamento da noção de prazer na Ética a Nicômaco. Como a mimese implica reconhecimento na descoberta do que o mimema manifesta, temos thauma, nos surpreendemos ao compreender que "este é aquele". Assim, a noção de mimese aproxima-se do saber. Lembremos ainda que mimese é considerada algo próprio da natureza humana na Poética, assim como a nossa propensão para o saber (Metafísica I).

A observação e apreciação da semelhança (homoites) pode nos levar a entender que Aristóteles esteja afirmando que apreciamos as obras miméticas como cópias de alguma coisa real. No caso dos retratos, isso provavelmente é verdadeiro, mas as pinturas não se limitam a retratos; elas podiam 
apresentar seres, ou objetos, que existam apenas na imaginação humana, como é o caso de muitos dos seres da mitologia, por exemplo. Além disso, a apreciação da semelhança nos põe a observar traços que caracterizam as coisas e levam ao reconhecimento.

Como pontua Halliwell, no dia-a-dia percebemos semelhanças nas coisas observando certas qualidades ou propiedades comuns entre elas; quando passamos a observar uma obra mimética, essa percepção que temos das coisas em geral está envolvida no reconhecimento de certos traços característicos como traços significantes por si mesmos, e que nos permitem perceber a semelhança que a pintura apresenta com seu modelo. Portanto, a compreensão da semelhança é um modo de interpretar o que o mimema apresenta, não é apenas uma constatação de similaridades, mas discernimento compreensivo e interpretativo do que está manifesto no mimema. ${ }^{39}$

Considerar "este é aquele" é ter uma percepção de tipo acidental, pois este tipo de percepção lida com a observação de certas características e da afirmação do que seja o que se observa; por exemplo, é afirmar que o que é visto seja um cão de uma determinada cor. ${ }^{40}$ Para Aristóteles forma-se uma imagem mental a partir do que a percepção capta, e tal imagem é representação daquilo que é percebido. ${ }^{41} \mathrm{O}$ reconhecimento do mimema implica a atividade da capacidade humana de entendimento ao associar a imitação com a coisa mesma; por isso a mimese causa prazer. A mimética não se identifica com o conhecimento, isto é, conhecimento e mimese não são o mesmo; o caráter prazeroso desta está relacionado à compreensão do que está representado em uma pintura ou escultura. Por meio de mimese compreendemos o que é representado e nos aprazemos com isto, visto que a compreensão do mimema proporciona prazer.

Para alguns comentadores, e mesmo tradutores da Poética, a passagem da mimese pictórica do capítulo quatro é digressiva e paradoxal quando comparada à outra poiesis marcantemente presente no tratado, a tragédia. ${ }^{42}$ Não concordamos com esta assertiva, mas, ao contrário, entendemos haver uma conexão entre ambas as passagens, como já defenderam alguns intérpretes recentemente. ${ }^{43} \mathrm{~A}$ tragédia é, como todo tipo de atividade citada na Poética, mimese, mais especificamente é mimese de ações humanas que provoca as emoções dolorosas de piedade e temor e, além disso, como o capítulo quatorze nos informa, a tragédia causa também prazer. O poeta 
deve esmerar-se em elaborar sua trama trágica para provocar o que parece, à primeira vista, se tomarmos rapidamente, paradoxal, dor e prazer.

O prazer que vimos até aqui associado à mimese é o prazer no reconhecimento. Para alguns estudiosos do texto, o prazer trágico é devido ao fato de reconhecermos que a tragédia é mimese, e por isso sentimos prazer ao percebermos que estamos diante de uma representação; sendo assim, ocorre uma mudança nos sentimentos por percebermos que estamos diante de um mimema (DUPONT-ROC; LALLOT, 1980, p. 189).

$\mathrm{O}$ reconhecimento associado à mimese, como vimos ao analisar a passagem da pintura no capítulo quatro, é o reconhecimento do que a pintura manifesta com seus recursos, a saber, é a simulação através do desenho e das cores que formam o mimema. No caso da tragédia, essa por ser poesia vale-se de palavras e de certa conexão entre os fatos e ações que apresenta, e tais elementos constitutivos do mythos deve provocar as emoções dolorosas e prazer nos espectadores ou leitores. E o fato da tragédia causar este último - o prazer -, não significa que deixemos de sentir as dores. ${ }^{44}$

As emoções que a tragédia provoca são sentidas em seu desfecho, e, a nosso ver, elas não deixam de ser dolorosas, não há uma "alquimia mimética", como se expressam os tradutores Dupont-Roc e Lallot, que as transforma em prazer ao percebermos que a situação dolorosa que as provocou é mimese. O prazer, assim como em Poética 4, é de reconhecimento e o que reconhecemos em uma tragédia são as ações dos personagens, os acontecimentos que lhes ocorrem, em suma, todos os fatos que levam ao fim trágico. Compreende-se então tudo o que suscitou as dores de piedade e temor, compreende-se que o prazer está no reconhecimento da seriedade da ação apresentada, e não em percebermos que a tragédia é mimese e por isso sentimos alívio da sensação dolorosa. ${ }^{45} \mathrm{O}$ prazer, nesse sentido, está na compreensão do todo que compõe uma tragédia, e só o experimentamos em sua finalização, quando entendemos os fatos e as ações humanas que causaram as dores. Compreendemos, então, a seriedade daquilo que o mimema trágico apresenta.

$\mathrm{Na}$ verdade, por Poética 14 (1453 b1-14), pode parecer que o prazer que sentimos se deve à piedade e ao medo, como se as dores fossem as responsáveis por se sentir prazer em uma tragédia; mas em realidade o prazer que sentimos provém da imitação dos fatos que suscitam tais emoções, que são fatos amedrontadores e piedosos; não são as dores que 
provocam o prazer, elas não causam o seu oposto, mas é a compreensão da ação apresentada pelo poema trágico que o provoca. ${ }^{46}$ Por isso, não há um paradoxo entre dor e prazer, há a presença de um e de outro. O prazer trágico é compreender o quão séria é a ação humana que está ali representada. Quando Aristóteles diz em Poética 1448 b16-17 “entender e inferir cada elemento", aplicado à tragédia isso abrange os personagens, as ações desenroladas, as emoções, os eventos, os argumentos em todas as facetas que aparecem e em seus inter-relacionamentos; por isso o prazer é sentido no final da trama, quando esse todo é finalmente compreendido pelo leitor ou pelo espectador. ${ }^{47}$

Dessa forma, o prazer típico de mimese da pintura no capítulo quatro não se contradiz ao prazer da mimese de ações que é a tragédia. O prazer, em ambas as passagens, é de ordem cognitiva: enquanto a cognição apresentada em Poética 4 é a que diz respeito ao reconhecimento do que é retratado pelo mimema pictórico, a cognição dos fatos e das ações que a tragédia apresenta é o que causa o prazer da tragédia, e tal prazer é próprio da mimese. ${ }^{48}$

Podemos objetar que a tragédia seja muito diferente da pintura ou da escultura, mas não devemos esquecer que Aristóteles nos diz que essas também podem apresentar animais terríveis ou figuras como as de pessoas mortas e, mesmo assim, nos comprazemos na observação de tais cenas. Isso se deve porque nos deleitamos no reconhecimento do que é apresentado, por isso sentimos prazer em ver e reconhecer coisas na pintura e na trama trágica, que, se vistas diretamente, são desagradáveis. ${ }^{49}$ Portanto, não é a piedade e o temor que provocam o prazer da tragédia, mas o prazer é provocado pela compreensão dos fatos temerosos e piedosos; é o entendimento dos fatos, que reconhecemos também como os causadores das dores, que proporciona o prazer apropriado a uma tragédia. ${ }^{50}$ Dessa forma, a trama trágica apresenta tanto emoções dolorosas quanto prazer.

Mesmo não havendo uma compreensão de mimese capaz de afastar as dúvidas que algumas passagens da Poética apresentam - lembrando o caráter fragmentário e interpolado com o qual a obra nos chegou -, podemos entender que a transposição mimética feita especialmente por pintores e poetas em suas obras mantém as acepções do verbo mimeisthai em Aristóteles como nos autores do século V a.C., embora a acepção de simulação esteja mais presente na obra como são o caso da pintura e da 
tragédia, que são simulações de caracteres e de ação, ou seja, de aspectos da vida.

Apesar da acepção simulativa claramente estar presente na obra de Aristóteles, a emulação também aparece, em especial quando Aristóteles cita o exemplo que os poetas devem seguir, como Homero e os bons pintores. Os mimemata, que são a poesia e a pintura, apresentam o real como todo mimema, ou seja, com semelhanças e diferenças quanto ao modelo, em suma, há um referencial que permite ao espectador ou ao leitor reconhecer o que ali se apresenta através do mimema, sejam simulações de ações humanas vindas da história, da mitologia, ou da mente do autor, e, assim nos maravilhamos com a perícia (techne) desse "fazedor de imagens", que é um teknites e, consequentemente, um poietes que, por meio de mimese, nos apresenta algo como se fosse ele mesmo.

${ }^{1}$ O presente artigo é parte da tese de doutorado "Catarse, emoção e prazer na Poética de Aristóteles" defendida na PUC-Rio em 2009, com acréscimos dos resultados do projeto de pesquisa “A noção de techne em Platão e Aristóteles" (Cadastro PROPP nº 00220.1700.959), desenvolvido na UESC de junho de 2010 a outubro de 2013.

${ }^{2}$ A expressão mimetikai technai é cunhada por Platão no Sofista. A palavra mimesis geralmente é traduzida por imitação ou por representação; ambas as traduções apresentam as acepções de mimesis. Volta e meia usamos aqui a palavra "mimese" em português, mas também as palavras imitação ou representação para traduzir a palavra grega. Falaremos disso mais à frente.

${ }^{3}$ Entre os autores do século V a.C. podemos citar: Sófocles, Ésquilo, Eurípedes, Demóstenes, Górgias, Aristófanes, Heródoto, Tucídides, Demócrito e Xenofonte.

${ }^{4}$ Cf. HALLIWELL, S. Aristotelian Mimesis Reevaluated. Journal of the History of Philosophy 28, 1990, p. 489-490. Sobre mimesis no contexto metafisico do pensamento aristotélico ver, por exemplo, Le problème de l'être chez Aristote. Essai sur la problématique aristotélicienne. Paris: Puf, várias reimpressões, de Pierre Aubenque, recentemente publicada em português pela Paulus. Para a amplitude da questão no corpus aristotélico verVELOSO, Cláudio William, Aristóteles Mimético. São Paulo: Discurso Editorial, 2004.

${ }^{5}$ Cf. HALLIWELL, S. Aristotelian Mimesis Reevaluated. p. 489-490. Apesar de mimese não ser definida na Poética, a maioria dos comentadores entende ser ela a noção central da obra. Cf. DUPONT-ROC, Roselyne; LALLOT, Jean. Aristote. La Poétique. Texte, traduction, notes par. Paris: Seuil, 1980. p. 155. Cf. também RICOEUR, Paul. Leituras $2-A$ região dos filósofos. Tradução de Marcelo Perine e Nicolas Nyimi Campário. São Paulo: Loyola, 1996. p. 330. A noção grega techne, que traduzimos por arte ou técnica, indica um saber que apresenta caráter teorético e aplicativo, estando próximo ao saber epistêmico, científico. Por ter proximidade com o conhecimento epistêmico, a noção garantia certo status às atividades, sendo comum

doispontos, Curitiba, São Carlos, vol. 11, n. 1, p.11-38, abril, 2014 
várias áreas autodenominarem-se techne. Nos autores do século V a.C., a noção de techne primeiramente designava a atividade do marceneiro (tekton), e do ferreiro, para posteriormente referir-se a outros peritos (technites), como o médico e, dessa forma, essa noção alargou o horizonte de sua aplicação, passando também a ser destacado seu caráter epistemológico, como nos testemunham alguns escritos médicos hipocráticos (Sobre a Técnica e Da Medicina Antiga). Aristóteles e Platão concordam quanto aos laços entre techne e episteme (ciência), mas o primeiro especifica com mais clareza - Metafísica I 1 e Ética a Nicômaco VI - o que é próprio de quem possui tal habilidade e o que a distingue da ciência. Esta última lida com temas que existem quase sempre, como o Motor Imóvel e as Esferas Celestes, ou relações matemáticas, como as propriedades de um triângulo retângulo, enquanto a techne lida com o contingente, com o que o homem pode produzir, seja a saúde de um paciente, uma casa, um navio, um poema trágico, etc.

${ }^{6}$ Em sua obra, Sörbom apenas analisa as palavras ligadas a mimeisthai quando se referem às obras de arte. Else, por sua vez, faz uma análise mais extensa das ocorrências dos vocábulos ligados a mimeisthai no século V a.C. em seu artigo.Ver também a obra de C.W.Veloso citada anteriormente, que discute longamente o artigo de Else e a livro de Sörbom que usamos aqui, além de apresentar seu próprio ponto de vista. No livro, o trecho que nos atemos corresponde à seguinte passagem: "Apêndice: A família de mimeomai no quinto século a.C.”, p.733-823. Usamos neste artigo o texto da tese de Veloso de 1999, que não difere em conteúdo do livro.

${ }^{7}$ Else observa que talvez essa fosse a razão dos atenienses considerarem o mimos estrangeiro e vulgar. Cf. ELSE, 1958, p. 76.

${ }^{8}$ Homero, Hinos, I 162-164. Os cognatos aparecem também na tragédia Coéforas de Ésquilo (525-456 a.C) e em um fragmento atribuído a este autor, que seria de uma obra sua intitulada Os Edônios, cujos fragmentos encontram-se conservados em Estrabão, onde encontramos mimoi, o plural de mimos, significando a simulação dos mugidos de touros. (Hedonoi, frag. 57 Cf. Estrabão X 16 (470F) In NAUCK, Augustus (recensuit) Tragicorum Graecorum Fragmenta, apud.VELOSO, C. W. loc. cit., p. 509). De acordo com Hermann von Koller, a primeira aparição dos vocábulos ligados a mimesis estaria em Heráclito, testemunhado no pseudo-aristotélico De mundo 5, 396b 7 (Cf. frag. B 10 Diels): He techne tem physin mimoumene. Mas o caráter problemático da fonte, cuja autenticidade é questionada, faz Else achar incorreta tal atribuição a Heráclito (ELSE, 1958, p. 82). Cf. KOLLER, Hermann Von. Der Mimesis in der Antike. Nachahmung, Darstellung, Ausdruck. Bernae Aedibus A. Francke, 1954. passim.

${ }^{9}$ Semelhante sentido apresenta um dos cognatos nas Coéforas, onde a personagem Orestes diz a seu primo Pílades que ambos simulem o sotaque para parecerem naturais da Fócida. No caso, o realizador do mimema pretende enganar seus observadores, uma vez que o que se imita deve ser tomado como o modelo da imitação. A passagem é a seguinte: "Falaremos ambos como se fôssemos nativos do Parnasso, imitando [mimoumeno] a linguagem dos foceus de lá." ÉSQUILO, Coéforas 563-564. In. Oréstia: Agamêmnon. Coéforas. Eumêmides. Tradução de Mário da Gama Kury. 4. ed. Rio de Janeiro: Jorge Zahar, 1999. Cf. SÖRBOM, 1966, p. 29-33. Curioso notar que Pílades é focense, mas também deve esforçar-se para exibir claramente certos sons que caracterizem o dialeto da Fócida, se quiser, junto com Orestes, ter sua proveniência reconhecida.

doispontos, Curitiba, São Carlos, vol. 11, n. 1, p.11-38, abril, 2014 
${ }^{10}$ Cf. ELSE, 1958, p. 79. Os casos a e $c$ da classificação de Else parecem indicar simulação e o caso $b$ emulação. Cf. observação de VELOSO, 1999, p. 524. Paul Woodruf acredita que a noção de mimesis seja unitária em Aristóteles e que, no caso das mimetikai technai presentes na Poética, estaria sempre presente a questão do engano, embora ele curiosamente considere este um "engano benigno", do qual tanto os espectadores, como os leitores aceitam participar, tendo plena consciência de que não estão diante de um fato verdadeiro. Cf.WOODRUFF, P. "Aristotle on Mimesis". In RORTY, A. O. (ed) Essays on Aristotle's Poetics. Princeton: Princeton University Press, 1992. p. 82ss.

${ }^{11}$ Sörbom deixa claro que, na maioria das vezes, o mimema é tomado como o modelo, isto é, causa de engano. Cf. SÖRBOM, 1966. p. 33. Como dissemos acima, tanto Sörbom quanto Else ligam a questão do engano aos cognatos de mimeisthai desde seus primórdios nos mimoi. Veloso discorda desta conviç̧ão, pois acredita que o engano concerne especialmente ao espectador e, ainda segundo ele, a acepção destes vocábulos que ocasionam engano é a emulativa e não a simulativa, como entende Sörbom. O engano se dá, por parte de quem observa, em procurar a própria coisa naquilo que é simplesmente imitação, ao invés de simplesmente esperar ver sua aparição ou exibição. Aquele que simula não pretende com isso apresentar algo distinto da própria simulação, enquanto o que emula faz isso na intenção de agir ou ser como aquele que está sendo emulado, podendo enganar-se com o modelo emulado e enganar a quem o observa. Cf.VELOSO, 1999, p. 548.

12 Recordemos as espécies de poesia relacionadas na Poética: epopeia, comédia, tragédia, ditirambo, aulética, citarística e nomo. Excetuando as duas primeiras, que voltam a aparecer no texto, analisadas comparativamente à tragédia, as demais são apenas citadas. Não comentamos aqui a parte em que Aristóteles procura a origem da poesia - início do capítulo quatro -, e suas considerações sobre mimese em tal passagem. Porém, retomaremos tal passagem mais à frente.

13 Poética 4, 1448 b20-26. Tradução de Eudoro de Sousa. Lisboa: Imprensa Nacional/Casa da Moeda, 1986. Modificamos aqui a tradução feita por E. de Sousa da palavra grega eutelesteroi, "baixas inclinações"; preferimos traduzi-la por "inferiores". Sobre a naturalidade do ritmo e da harmonia ver ainda PolíticaVIII, 1340 a3-5: "ela [a música] associa-se a um prazer natural e por isso o seu uso agrada a todas as idades e caracteres". Tradução de António C. Amaral e Carlos C. Gomes. Lisboa:Vega, 1998. De acordo com Gudeman, nessa passagem da Poética, Aristóteles estaria recusando as "teorias da inspiração divina" da poesia, apesar de em alguns lugares Aristóteles referir-se ao poeta como um inspirado: "Eis por que o poeta é conforme a seres bem dotados ou a temperamentos exaltados, a uns porque plasmável é a sua natureza, a outros por virtude do êxtase que os arrebata". Poética 17, 1455a 33. Cf. Gudeman, apud. Eudoro de Sousa, "Comentário". In Poética p. 111.

14 Cf.V. G. Yebra, op. cit., nota 62, p. 255. Ainda de acordo com Yebra, a ideia de que a poesia homérica foi precedida de outros poetas, embora pouco se saiba deles, era corrente na antiguidade. Este comentador ainda lembra que essa ideia de desenvolvimento da poesia é a raiz das leituras que acreditam na recusa de Aristóteles da mania poética. Homero estaria na origem da comédia com uma obra sua chamada Margites (hoje perdida), e na origem da tragédia, com as epopeias Ilíada e Odisseia, que serviram de fonte para os trágicos, além de seus hinos aos deuses servirem a poetas líricos, por exemplo.

doispontos, Curitiba, São Carlos, vol. 11, n. 1, p.11-38, abril, 2014 
15 Como bem observa Veloso, se estivessem os poetas apenas simulando, não se entenderia o porquê da preferência deles por uma das três espécies de poesia. Cf. VELOSO, 1999, p. 233-234.

16 Retórica II 6, 1384 b35-1385 a1. Tradução nossa a partir do texto grego da Loeb, cotejada por sua tradução e pelas traduções da Imprensa Nacional-Casa da Moeda e da Gredos. No prefácio à edição da Retórica das Paixões, que corresponde ao livro II da Retórica, capítulos 1 ao 11, Michel Meyer associa emulação com mimesis: "A inveja dirige-se para os iguais, assim como a emulação; a inveja quer tirar do outro o que ele tem, a emulação quer imitá-lo. São reações que tendem a prolongar a simetria ou criá-la, visto que uma deseja gerar a diferença, a outra, a identidade." Id. Ibid. Tradução de Isis Borges B. da Fonseca. São Paulo: Martins Fontes, 2003. p. XLVI. Com base nisso, Veloso faz a seguinte consideração: "Pode-se dizer então que a emulação seria, de algum modo, a 'natureza imitativa' do homem da qual se fala na Poetica: nossa physis chama-se dzelos. Natureza, evidentemente, emotiva." Cf.VELOSO, 1999, p. 147.

17 Poética 15, 1454 b 8-10. Tradução de Eudoro de Sousa. In op. cit. Cf. JANKO, Richard. Aristotle Poetics I. Indianápolis-Cambridge: Hackett Publishing, 1987. p. 220. Para DupontRoc e Lallot, essa passagem, assim como a passagem do capítulo 22, indicaria o "objeto-cópia”, a imitação de algo tomado como modelo ou exemplo. No caso do capítulo 22 , teríamos como objeto-cópia, segundo os tradutores franceses, a linguagem corrente: "nos jâmbicos, ao invés, e porque neles se imitam a linguagem corrente, mais convêm os nomes que todos adotam na conversação, a saber, nomes correntes, metáforas e ornatos." Poética 22, 1459 a11-13. Nestas duas passagens, capítulos 15 e 22, Dupont-Roc e Lallot acreditam que a tradução tradicional por "imitação" não traria prejuízos para se entender a família de mimese. Cf. DUPONTROC, R.; LALLOT, J., 1980, p. 17-20. A nosso ver, se bem compreendida, a tradução de mimesis por imitação não traz prejuízo a nenhuma passagem da obra.

${ }^{18} \mathrm{Na}$ Retórica, Aristóteles fala literalmente da predileção de Homero por Aquiles: "É bom também aqueles que têm preferido alguém entre os sensatos ou homens e mulheres bons - como, por exemplo, Atena a Odisseo, Teseu a Helena, as deusas a Alexandre e Homero a Aquiles - e, em geral, o que é digno de escolha" Retórica I, 1363 a17-20. Tradução nossa com base no texto grego da Loeb, cotejada por sua tradução e pelas traduções da Casa da Moeda e da Gredos. O que é digno de preferência é aquilo que é objeto de escolha, e este é o mesmo que o objeto da deliberação (proairesis): "o objeto de escolha é algo ao nosso alcance, que desejamos após deliberar, a escolha será um desejo deliberado de coisas a nosso alcance”. Cf. Ética a Nicômaco III, 1113 a11.

${ }^{19}$ Cf.VELOSO, 1999, p. 232ss. Halliwell considera que a presença das acepções de mimeisthai de maneira às vezes indissociável, é uma peculiaridade apenas das mimetikai technai presentes na Poética. Mas essa é uma questão de difícil conclusão, vide o que destacamos anteriormente sobre os contextos de mimese. Cf. HALLIWELL, Aristotle's Poetics, p. 115-116.

${ }^{20}$ Cf. Diógenes Laércio, Vidas e doutrinas dos filósofos ilustres.VIII, 57. Empédocles é uma personalidade mista de cientista e místico, a quem Aristóteles em um diálogo de juventude, perdido (Sofista), atribuiu a invenção da retórica. Ele também teria fundado a escola italiana (Sicília) de medicina que, segundo Claudio Galeno (130-199 d.C.), rivalizou com as escolas de Cós (hipocrática) e Cnido. Galeno, apud. John Burnet, 2006, p. 219. Essa escola de medicina existia na época de Platão e influenciou a este e a Aristóteles. Dodds considera Empédocles, além de

doispontos, Curitiba, São Carlos, vol. 11, n. 1, p.11-38, abril, 2014 
xamã grego, um verdadeiro poeta e não um filósofo que escreve em versos. Cf. E. R. Dodds, 2002 , nota 115 , p. 176. Outro poema que nos chegou dele foi o Sobre a Natureza. É bem provável que o próprio Empédocles, assim como Pitágoras, tenha contribuído para as lendas que rondam sua pessoa. Cf. DODDS, 2002, p. 148. Segundo um historiador siciliano da antiguidade, de nome Timeu, Empédocles teria sido expulso do círculo pitagórico por furtar discursos. Cf. Diógenes Laércio, op. cit., VIII 54 e BURNET, 2006, p. 218. Mesmo que essa história não seja verídica, ao que tudo indica, parece que o orfismo foi influente em Agrigento, cidade natal de Empédocles, na época em que este vivia. Cf. BURNET, Ibid. Burnet nos informa também que o fragmento 129, de modo geral, se refere a Pitágoras. Id. Ibid., p. 219.

${ }^{21}$ Poética 9, 1451 b27-31. Tradução de Eudoro de Sousa. In op. cit.

${ }^{22}$ Retórica III, 1404 a20-23. Tradução nossa a partir do texto grego da Loeb cotejada por sua tradução e pela tradução da Gredos e da Casa da Moeda.

${ }^{23}$ Poética 2, 1448 a1-18. Tradução de Eudoro de Sousa. In op. cit.

${ }^{24}$ Cf. R. Dupont-Roc e J. Lallot, op. cit., p. 156. Segundo os tradutores franceses, a palavra "imitação" não daria o segundo sentido. Mas, lembremos, tanto quanto a palavra representação, preferida por estes tradutores, o termo imitação mantém as acepções de simulação e emulação.

25 Cf. SÖRBOM, 1966, p. 119-120 e 191-197, respectivamente. Fora da Poética, Sörbom encontra a família de mimeisthai no sentido de subject-matter na Ética a Nicômaco III, 1113 a8-9: "Isto pode ser ilustrado pelas antigas constituições tais como Homero mostra [em seus poemas], onde os reis anunciavam ao povo as medidas escolhidas."

${ }^{26}$ Cf. DUPONT-ROC; LALLOT, 1980, p. 157. Além desses ethe, outros aparecem na Poética, como a virtude e a maldade, paradigma tanto ético quanto da estratificação social grega. Id. Ibid.

27 Cf.YeBRA, 1974, nota 46, p. 251-252. Continua Yebra: “Além disso, careceria de sentido dizer que o poeta 'pode imitar' (mimeisthai estin) a todos os atores atuando ('acting', traduz Else), pois os atores são por definição atuantes, e não podem ser apresentados de outro modo; enquanto que as personagens de uma ação podem ser apresentados (imitados) pelo poeta ou mediante narração (indireta, como a de Homero, ou direta, como a dos maus poetas épicos), ou apresentando-os diretamente na ação (por meio dos atores, se a ação se representa no teatro, ou sem atores, na obra dramática escrita)." Id. Ibid. Tradução nossa.

${ }^{28}$ Poética 24, 1460 a5-11. Tradução de Eudoro de Sousa. In op. cit.

${ }^{29}$ Cf.VELOSO, 1999, p. 84.Veloso nota que no proêmio é o poeta que fala na primeira pessoa e no início na poesia épica e em Eurípides, respectivamente. Id. Ibid. Sobre o proêmio ver ainda Retórica III 14, 1415 a8-25.

${ }^{30}$ Jean Lallot, apud.VELOSO, 1999, p. 82. "Para Lallot quem não imita seria quem fala em sua própria pessoa, como se supõe que o poeta faça no proêmio". Id. Ibid. Veloso cita o seguinte artigo de Jean Lallot: "La mimesis selon Aristote et l'excellence d'Homère". In LALLOT, J. \& LE BOULUEC. Escritures et théorie poétiques.

31 Poética 25, 1460 b8-12. Tradução de Eudoro de Sousa. In op. cit. Traduzimos aqui eikonotta hos por "fazedor de imagens" e não por "imaginário" como traduz E. de Sousa.

doispontos, Curitiba, São Carlos, vol. 11, n. 1, p.11-38, abril, 2014 
32 Segundo Dupont-Roc e Lallot, esse referente da mimese mostra sua vinculação a algo externo. Cf. DUPONT-ROC; LALLOT, 1980, nota 2, p. 387.

33 Poética 25, 1460 b31-36. Tradução de Eudoro de Sousa. In op. cit.

34 Como a maior parte dos escritos aristotélicos que a tradição nos transmitiu, a Poética está inserida no grupo dos esotéricos ou acroamáticos, classificação esta que indica que estes textos se dirigiam aos estudos internos da escola de Aristóteles, o Liceu, e não ao público externo. Tal classificação também indica a situação do texto: notas de aulas, do filósofo ou dos discípulos, em que certos temas e noções podem aparecer apenas enunciados. Além disso, muitos dos manuscritos da obra apresentam notas marginais, possivelmente feitas por copistas medievais:“... aqui advertimos que a Poética está desagregada por anotações marginais e pequenas adições.” Cf. DÜRING, Ingemar. Aristóteles. Tradução de Barnabé Navarro. 2. ed. México: Universidad Nacional Autónoma de México, 1990. p. 206. Ou, ainda, como adverte Eudoro de Sousa sobre a situação do texto: "Nenhum outro [texto aristotélico] se nos afigura mais 'torturado' por notas marginais, expressões parentéticas e acréscimos sucessivos, do que este..." Cf. "Introdução” In Aristóteles Poética.Tradução, Prefácio, Introdução, Comentário e Apêndices de. Lisboa: Imprensa Nacional-Casa da Moeda, 1986. p. 26.

35 Poética 4, 1448b 4-24. Tradução nossa a partir do grego da Loeb, cotejada por sua tradução e pelas traduções da Imprensa Nacional, Gredos e Calouste Gulbenkian. O prazer ligado à mimese é de ordem cognitiva, mas aqui também há um outro tipo de prazer, o de ordem sensível, devido ao uso da cor, etc. Para os vários tipos de prazer no pensamento aristotélico, ver a antologia referente à Ética a Nicômaco seguida de notas e dois apêndices explicativos na obra LAURENTI, R Aristotele, Scritti sul Piacere. A cura di Renato Laurenti. Palermo: Aesthetica, 1989. Quanto à semelhança, Halliwell lembra que nesse contexto do pensamento aristotélico, podemos entender esta quase como sinônimo de mimese. Cf. "Pleasure, understanding and emotion in Aristotle's Poetics", p. 245. Ver ainda nota abaixo.

36 "Este é aquele" traduz houtos ekeinos. "Este" indica o que está traçado ou desenhado e "aquele" o que foi antes visto.Ver comentário a esse respeito em V. G.Yebra, "Notas à tradução espanhola" In Aristóteles Poética, nota 59, p. 254. Gerald Else lembra uma variante nos manuscritos da expressão grega: touto ekeino, que aparece também em Retórica I 11. Cf. ELSE, Aristotle's Poetics: The Argument. p. 131-132.

${ }^{37}$ Sobre o reconhecimento do que o mimema manifesta ver ainda Tópicos VI 2, 140a 18-22.

38 Cf. Retórica I 11, 1371a 21-1371b 17. Tradução nossa a partir do texto grego da Loeb, cotejada por sua tradução e pelas traduções da Oxford, Gredos e Imprensa Nacional-Casa da Moeda. Sobre o maravilhoso lembremos Poética 24, 1460 a17: "O maravilhoso é agradável" (To de thaumaston hedy).

${ }^{39}$ Sobre a relevância da semelhança para os argumentos da filosofia ver Tópicos 108 b7-12. Sobre a relação da semelhança com a metáfora ver Tópicos 140 a8-10, Retórica 1410 b10-19, 1412 a9-12, Poética 1459 a5-8. E sobre a importância da semelhança para a interpretação dos sonhos e para as analogias retóricas ver De Divinatione Somniorum 464 b5-12; e Retórica 1394 a2-9. Cf. observação de HALLIWELL, "Pleasure, understanding and emotion in Aristotle's Poetics", p. 245. Além disso, Halliwell recorda que o discernimento da semelhança não indica uma observação passiva e superficial de similaridades; ao se observar a semelhança na filosofia,

doispontos, Curitiba, São Carlos, vol. 11, n. 1, p.11-38, abril, 2014 
na metáfora, na interpretação dos sonhos e na arte, o tipo de discernimento envolvido nem sempre é bem realizado por todos, ou pelo menos nem todos o fazem igualmente bem. Cf. S. Halliwell, id. ibid., p. 247.

${ }^{40}$ É típica da percepção acidental a expressão "este é aquele": "Denomina-se sensível por acidente quando, por exemplo, este branco é filho de Diares. Porque se percebe isto por acidente, pois é acidental ao branco o fato de ele se unir a tal objeto, o qual é apreendido pelos sentidos." De Anima II 418 a20-23.Ver também Id. Ibid. III, 425 a24-30.

${ }^{41}$ Cf. De memoria 450 a. Lembremos que a percepção ou sensação (aisthesis) é o princípio do processo de cognição humana: no sensível, tudo é constituído de matéria e forma, e a percepção discrimina a forma da matéria, retirando o que há de inteligível no sensível, "recolhendo" o que o intelecto (nous) trabalha, pois ele lida com os inteligíveis Cf. De Anima II, passim. As imagens mentais ainda referem-se ao que possa ser pensado: conceitos, opiniões, deliberações, valores, etc. De Anima III, 432 a5-10. Em uma passagem famosa, Aristóteles considera que "a alma nunca pensa sem recorrer a uma imagem.” Cf. Id. Ibid., III, 431 a18-19.

${ }^{42}$ Cf. consideram os tradutores DUPONT-ROC; LALLOT, 1980, p. 189.

43 Cf. NUSSBAUM, 2009, p. 331-345; Cf. S. Halliwell. "Pleasure, understanding and emotion in Aristotle's Poetics", p. 241-260; Cf.VELOSO, 1999, p. 13-25. Defendemos posição semelhante em artigo publicado: "Sobre o prazer da tragédia em Aristóteles". Anais de Filosofia Clássica, vol 3, n 6, Rio de Janeiro, 2009. p. 85-92.

${ }^{44}$ Cf. Elisabeth Belfiore, Pleasure, Tragedy and Aristotelian Psychology. Classical Quartely N. S. 35, 1985. p. 349-361. p. 349; Cf. Jonathan Lear, "Katharsis". In. RORTY, A. O. (ed), op. cit., p. 315-340. p. 302. Cf. S. Halliwell, "Pleasure, understanding and emotion in Aristotle's Poetics", p. 242.

45 Cf. NUSSBAUM, 2009, p. 341-342. A piedade e o temor são efeitos trágicos que devem já estar previstos na trama, pois não deve ser a encenação teatral a responsável por suscitá-las, mas a sua simples leitura. Cf. Poética 19,1456 b3-4. Nesse sentido, o poeta deve se atentar para a estruturação e ordenação dos fatos se quiser atingir o que é próprio de sua composição: "o efeito da tragédia deve resultar, unicamente, da composição dos fatos, da intriga, da íntima conexão das ações”. Cf. SOUSA, "Comentário”, Aristóteles. Poética. p. 133. Cf. também HALLIWELL, "Aristotelian Mimesis Reevaluated.” p. 246.

${ }^{46}$ Cf. Poética 19, 1456 b3-4. Ver ainda 9, 1452 a2-4 e também 13, 1452 b32-33 Que confirmam que a imitação não é só de uma ação completa; é, também, imitação de fatos que suscitam temor e piedade. Um trecho esclarecedor sobre a ligação do prazer com a função da tragédia é o seguinte:"se a tragédia se distingue em todas estas coisas e ainda no efeito próprio da arte (pois estas imitações devem produzir não um prazer qualquer mas o que já foi referido), é evidentemente superior, uma vez que atinge o seu objectivo melhor do que a epopéia." Cf. 1462 b12-14. O prazer já referido é o de 1453 b10-13. Cf. observação de Ana Maria Valente, Aristóteles. Poética. Lisboa: Calouste Gulbenkian, 2004. Nota 198, p. 106. Usamos aqui sua tradução para o trecho citado da obra.

47 Como bem observou Halliwell, "Pleasure, understanding and emotion in Aristotle's Poetics", p. 249. 
48 Cf. NUSSBAUM, 2009, p. 342. Cf. HALLIWELL, "Inside and outside the work of art: Aristotelian Mimesis Reevaluated." In The Aesthetics of mimesis: Ancient texts E modern problems, p. 161-162.

${ }^{49}$ Cf. Retórica I 11, 1371 b1-22; Poética 4, 1448 b4-24.

${ }^{50}$ Halliwell relembra que no capítulo quatro da Poética a ênfase estava na inter-relação da cognição com o prazer e, no caso da tragédia, o que é enfatizado, e está em primeiro plano, é a integração entre prazer, emoção e cognição. Nesse sentido, a apreciação da tragédia não apenas implica uma "compreensão preexistente do mundo", ela ainda proporciona o refinamento e a extensão dessa compreensão. Cf. HALLIWELL, "Pleasure, understanding and emotion in Aristotle's Poetics", p. 253.

\section{Referências bibliográficas}

ARISTÓTELES. Aristotle in Twenty-three Volumes. Cambridge-Mass./ London: Harvard University Press. (The Loeb Classical Library)

. The Works of Aristotle. Edited by W. D. Ross. Oxford: Oxford University Press.

. Ouvres Complètes. Paris: Belles Lettres. (Collection des Universités de France) 1951. Aristotle's Theory of Poetry and Fine Art. Translation by S. H. Butcher. 4. ed. New York: Dover. 1987. The Poetics of Aristotle. Translation \& commentary Stephen Halliwel. USA/London:The University of North of Carolina/ Chapel Hill. 1994. Poetics. Translation with a introduction by Gerald F. Else. The University of Michigan Press. 1957. Aristotle's Poetics: The Argument. Translated by Gerald F. Else. Cambridge (Mass.): Harvard University Press. 1980. La Poétique. Texte, traduction, notes par Roselyne Dupont-Roc et Jean Lallot. Paris: Seuil. 1974. Poética. Tradução trilíngüe grego, latim e espanhol de Valentín García Yebra. Madrid: Gredos. 
1986. Poética.Tradução, Prefácio, Introdução, Comentário e Apêndices de Eudoro de Sousa. Lisboa: Imprensa Nacional/Casa da Moeda. 2004. Poética. Prefácio de Maria Helena da Rocha Pereira; Tradução e Notas de Ana Maria Valente. Lisboa: Calouste Gulbenkian. . 1987. Poetics I. Translation Richard Janko. Indianápolis/ Cambridge: Hackett Publishing. 1954. The Rhetorics \& The Poetics of Aristotle. With an Introduction an Notes By Freiderich Solmsen. Translation by W. Rhys Roberts and Ingram Bywater. New York: Modern Library. 2003. Retórica das paixões. Livro II, Capítulos 1-11. Prefácio de Michel Meyer. Tradução bilíngüe grego-português de Isis Borges B. da Fonseca. São Paulo: Martins Fontes. 1994. Retórica. Introdução, tradução e notas de Quintín Racionero. Madrid: Gredos. 2006. Retórica. 3. ed. Tradução e notas de M. Alexandre Jr., P. F. Alberto e A. N. Pena. Lisboa: Imprensa Nacional-Casa da Moeda. (Biblioteca de Autores Clássicos)

2009. Ética a Nicômaco.Trad. de António de Castro Caeiro. São Paulo: Atlas. 2006. De Anima. Apres., trad. e notas de Maria Cecília Gomes dos Reis. São Paulo: Ed. 34. 1973. Ética a Nicômaco. Tópicos. Dos Argumentos Sofísticos. Poética. Tradução AAVV. São Paulo: Abril Cultural. (Os Pensadores IV) 1969. Metafísica. Trad. Leonel Vallandro. Prefácio de Sir David Ross. Porto Alegre: Globo.

BARNES, J. (ed). 1996. The Cambridge Companion to Aristotle. USA: Cambridge University Press.

BARNES, J. (org.). 2009. Aristóteles. Tradução de Ricardo Hermann Ploch Machado. Aparecida, SP: Idéias \& Letras. (Coleção Companions \& Companions) 
BARNES, J., SCHOFIELD, M. \& SORABJI, R. (ed.). 1979. Articles on Aristotle: 4. Psychology and Aesthetics. London: Duckworth.

BELFIORE, E.. 1985. Pleasure, Tragedy and Aristotelian Psychology. Classical Quartely N. S. 35, p. 349-361.

BRANDÃO, J. S. 2001. Mitologia Grega. 12. ed. São Paulo:Vozes.Vol. II. BURNET, J. 2006. A aurora da filosofia grega. Tradução de Vera Ribeiro. Rio de Janeiro: Contraponto/PUC-Rio.

DIÔGENES LAÊRTIOS. 2008. Vidas e doutrinas dos filósofos ilustres. Tradução e notas Mário da Gama Kury. 2. ed. Brasília: UnB.

DODDS, E. R. 2002. Os gregos e o irracional. Tradução de Paulo Domenech Oneto. São Paulo: Escuta.

DÜRING, I. 1990. Aristóteles. Tradução de Barnabé Navarro. 2. ed. México: Universidad Nacional Autónoma de México.

ELSE, G. F. 1958. "Imitation” in the Fifth Century. Classical Philology, v. LIII, n. 2, April, 1958.

ÉSQUILO. 1999. Coéforas 563-564. In: Oréstia: Agamêmnon. Coéforas. Eumêmides. Tradução de Mário da Gama Kury. 4. ed. Rio de Janeiro: Jorge Zahar.

HALLIWELL, S. 1990. Aristotelian Mimesis Reevaluated. Journal of the History of Philosophy 28, 1990.

2002. The Aesthetics of mimesis: Ancient texts \& modern problems. Princeton: Princeton University Press.

. Pleasure, Understanding, and Emotion in Aristotle's Poetics. In: RORTY, A. O. (ed), op. cit., p. 241-260.

KOLLER, H.. 1954. Der Mimesis in der Antike. Nachahmung, Darstellung, Ausdruck. Bernae Aedibus A. Francke.

LAURENTI, R. 1989. Aristotele, Scritti sul Piacere. A cura di. Palermo: Aesthetica. 
NUSSBAUM, M. 2009. A fragilidade da bondade: fortuna e ética na tragédia e na filosofia grega. Tradução de Ana Aguiar Cotrim. São Paulo: WMF Martins Fontes.

RICOEUR, P. 2000. A metáfora viva. Tradução de Dion Davi Macedo. São Paulo: Loyola. 2000. Entre retórica e poética: Aristóteles. In: A metáfora viva.Trad. Dion Davi Macedo. São Paulo, Loyola. (Leituras Filosóficas) 1994. O tecer da intriga: uma leitura da Poética de Aristóteles. In: Tempo e narrativa. Tomo I. Trad. Constança Marcondes César. Campinas, Papirus. 1996. Leituras 2 - A região dos filósofos. Tradução de Marcelo Perine e Nicolas Nyimi Campário. São Paulo: Loyola.

RORTY, Amélie Oksenberg (ed). 1992. Essays on Aristotle's Poetics. Princeton: Princeton University Press.

SÖRBOM, Göran. 1996. Mimesis and Art: Studies in the Origin and Early Development of an Aesthetic. Uppsala: Svenska Bokförlaget Bonniers.

VELOSO, C.W. 2004. Aristóteles Mimético. São Paulo: Discurso Editorial. 1999. Aristóteles Mimético. Tese de Doutoramento em

Filosofia. São Paulo: FFLCH/USP.

WOODRUFF, P. Aristotle on Mimesis. In: RORTY A. O. (ed), op. cit., p. 73-95. 